\title{
Design Aspirations for Energy Autarkic Information Systems in a Future with Limits
}

\author{
Brian Sutherland \\ Faculty of Information \\ University of Toronto \\ Toronto, Ontario, Canada \\ b.sutherland@utoronto.ca
}

\begin{abstract}
An information system is energy autarkic if its operation is integrally sustained by an ambient energy source, typically renewable, for long periods of time. An energy autarkic system's sustainability increases if the environmental cost for its design, material, construction, repair and recycling is minimal, the social value of its creation, use and disposal is widely justifiable over time and diverse contexts, and it has further potential as a usermodified, upcycled, or salvage system. In this essay I discuss a number of past solar-powered information system designs, comparing them with contemporary solar autarkic prototypes, reflecting on their actors, their histories and their socialtechnical trajectories. I conclude by proposing a set of aspirational design characteristics for sustainable autarkic computing systems, in as much as they represent a class of transitional computing aligned to a future with limits.
\end{abstract}

\section{CCS CONCEPTS}

Social and professional topics $\rightarrow$ Sustainability;

\section{KEYWORDS}

Materiality, sustainability, e-waste, history of information services, energy harvesting, consumerism, growth and postgrowth; emerging architectures

\section{Reference Format:}

Brian Sutherland. 2021. Design Aspirations for Sustainable Energy Autarkic Systems in a Future with Limits In LIMITS '21: Workshop on Computing within Limits, June 14-15, 2021.

\section{Energy Autarky}

Energy autarky is a simple strategy where the use of energy is tied directly to renewable generation nearby [1]. If we design

Permission to make digital or hard copies of part or all of this work for personal or classroom use is granted without fee provided that copies are not made or distributed for profit or commercial advantage and that copies bear this notice and the full citation on the first page. Copyrights for third-party components of this work must be honoured. For all other uses, contact the owner/author(s). LIMITS '21, June 14-15, 2021.

(C)2021 Copyright held by the owner/author(s). information systems to harness local, natural flows of energy such as wind, solar and the tides, while avoiding mineral sources of energy such as fossil fuels or nuclear fission, they incline naturally towards a local, low environmental impact. Design aspirations around energy autarkic information systems are concerned with the pursuit of high efficiency, resiliency strategies around intermittent decentralized power, and consideration to initial site selection or context of use, in the case of mobile systems. Just as a passive solar house benefits from a southern exposure and strategies like curtains being opened and closed in response to environmental conditions [2], energy autarkic information systems require the management and curation of sustainable power, energy storage or sleep strategies during energy-lean periods, as well as durable recovery of function. We might further posit the information system in its manufacture, materiality, durability, repair and recycling has a low environmental impact.

Indeed, mass manufacturing and consumption of computing causes a significant environmental impact in the world. Consider, for example the materials and energy required in the manufacture of 20-30 billion computing devices in use in 2020 [3], or the energy consumption of $4 \mathrm{~B}$ streaming video downloads of the official 'Gangnam Style' video, more electricity than a small country uses in a year [4]. Many devices also consume significant energy as standby power [5]. Aside from the consumption issue there is an equity one: the wealthiest billion people own $75 \%$ of devices [6]. In moving IT from desktop software and personal computers to the internet and the cloud, many coal fired and gas plants were engaged to support the increase in computing infrastructure [7][8].

If our information systems used renewably sourced ambient and stored energy, we might address an important aspect of this problem in the sense that energy independent devices provide information services on an ongoing basis without a central electricity supply. In a previous LIMITS paper Subramanya et. al. discuss 'energy-agility', strategies for optimizing computing for power which varies over time, a recognition that process efficiency for computing is bound to energy supply [9]. Raghavan et. al discusses material end to end dependencies for a self-sustainable internet in a paper on "internet quines"[10]. Another formative concept is Raghavan's benign computing, 
where computing devices horizontally scale, fail well (in the case of intermittent power), and aspire toward open design [11].

This work considers the designs of information systems that are self-sustaining or energy autarkic through a series of examples of solar-powered consumer products, which mass manufacturing tends to transform into a kind of horizontal scaling. These would be consistent with Borning et. al who suggested in LIMITS 2018 pushing back with designs that favour the natural environment over economic considerations [12]. That may not be necessary: the history of energy autarkic information devices is filled with many products which were economically successful, and several of which became permanent 'types'. Energy autarkic IT systems further reduce the sensitivity of systems to economic considerations in the sense that having been established, they continue to run without a marginal cost for electricity.

\section{Energy Autarkic Radios}

The earliest demonstration of an energy autarkic information system was Mouchot and Pifre's solar heated steam powered newspaper printer in the Tuileries gardens in 1878 [13]. Autarkic information systems in the electronic sense became possible with the invention of transistors in 1947, and then $6 \%$ efficient solar cells in 1954 at Bell Laboratories [14]. By 1956 the manufacturing cost of solar cells had been reduced and the efficiency increased to the point that solar powered transistor AM radios appeared in the market as luxury items. The Hoffman $\mathrm{P} 411$, the first solar powered consumer AM radio, used solar panels in the handle which stored electricity in nickel-cadmium rechargeable batteries, it was an energy autarkic system. These radios are extremely rare and valuable: a Hoffman P411 was auctioned on eBay recently for $\$ 2,383$ US.

The Hoffman Trans-Solar radio from 1959 pictured in Figure 1 is a later, lower cost version. It has the characteristic tessellated circular sector design of early solar panels, and because NiCad rechargeable batteries were difficult to obtain, it used a $4.2 \mathrm{~V}$ disposable mercury battery popular during World War II. The switch on the back would shift the power source from solar to battery. The front of the radio is was embossed with stars as Hoffman Electronics had used the same solar cells as were produced for the first US satellite, the Vanguard I. Advertisements for this radio discuss "the first practical consumer product resulting from outer space research" [15]. Materially speaking, of course, it is less than benign: the radio, as well as using mercury batteries, contains a lot of lead based solder and phenolic plastic.

Chapin, Fuller and Pearson's original invention of solar cells in 1954 was motivated by a limits problem. Daryl Chapin of the Bell research team was seeking a power source for use in the south as batteries tended to break down in humid climates [16]. In putting both transistor devices and solar powered systems together, Bell Laboratories ostensibly invented productintegrated photovoltaic devices, the scope of which is surveyed in works such as [17] and [18].

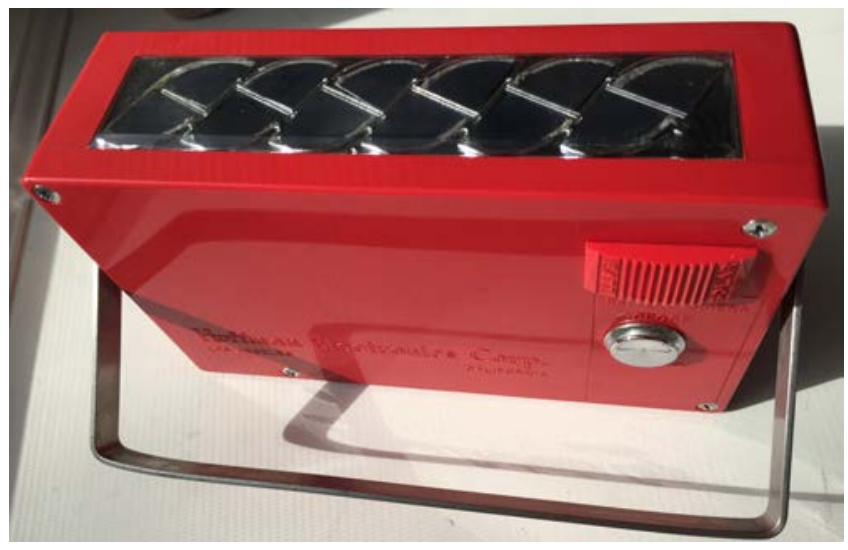

Figure 1: Hoffman RP-706 Solar Radio, 1959.

Bell Labs also explored the social implications of their research in a series of nine educational science films, viewed by millions. The first was "Our Mr. Sun" (1956) which presents a society powered by solar devices, e.g. "in full sun our family car receives almost enough energy to run it" [19], a future filled with solar consumer goods and economic prosperity. The fourth, "The Unchained Goddess" (1958) discusses weather and climate science, referring to the rising global temperatures induced by petroleum consumption, the melting of the polar ice caps, and were that to happen, "an inland sea would fill a good portion of the Mississippi valley" [20]. This latter film is perhaps that alternate future where limits on carbon are now a worldwide matter of concern.

It is quite common to find models of these early solar radios that still work in the sun. Many more solar radios were produced in later years by Hoffman, Zenith, Stromberg-Carlson, Nordemende, and then through the 1980s in Japan by Sanyo, Sony, and Crown, as well as in Soviet Russia. It is worth noting at this point that it was not only durability of solid state components and the efficiency gains of solar cells, but also transistors, 1,000,000 times more efficient than radio tubes, that made the transition to portable players possible. We might further question why energy aukartic media players aren't more common today, particularly as large companies like Apple hold so many patents in this area [21], [22].

One reason may be corporate culture and history. One of the AM solar radio products I examined was the Zenith Royal 555 'Sun Charger' introduced in 1965 . This radio's rechargeable batteries could be energized by house power, or by the solar panel in the handle. Zenith likely entered the market because of their previous success utilizing the 'free power of the wind' to sell 'Wind-Charger' radios during the 1930s. Zenith's wind- 
charger autarkic package featured a small wind generator along with a battery and a Zenith long-distance reception radio. It was typically sold to non-electrified, isolated farms [23]. Customers in Nairobi and other areas of the energy-poor Global South similarly purchase a media device with a solar panel today [24].

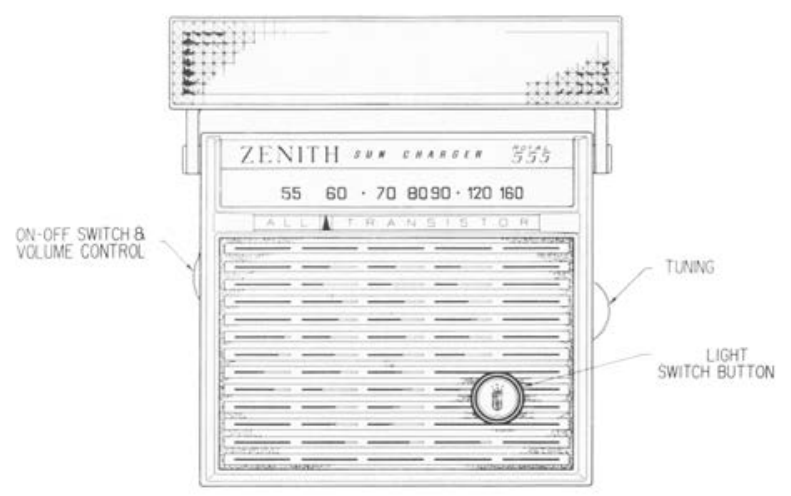

Figure 2: Zenith Royal 555 'Suncharger' Radio, 1965 (illustration courtesy of Zenith Electronics)

With the decline of American electronics manufacturing in the 1970s, the Zenith radio plant in Chicago, Illinois where the SunCharger was produced, became a blasted, abandoned hulk of twisted metal and broken glass, beside the railway station. We can assume from the material requirements of the manufacture of early electronics that there is environmental degradation at the site.

\section{Energy Autarkic Watches and Calculators}

As the locus of electronics manufacturing and solar power cell development started to shift to Japan, a series of new solar consumer products were being created that were energy autarkic. One of the most successful, aside from the ubiquitous solar calculator introduced by Sharp, is the Citizen Eco-Drive solar powered analog watch. The first model of this type came out in 1976, the Citizen Crystron Solar. It had eight solar cells on the face and could keep running for months in a drawer.

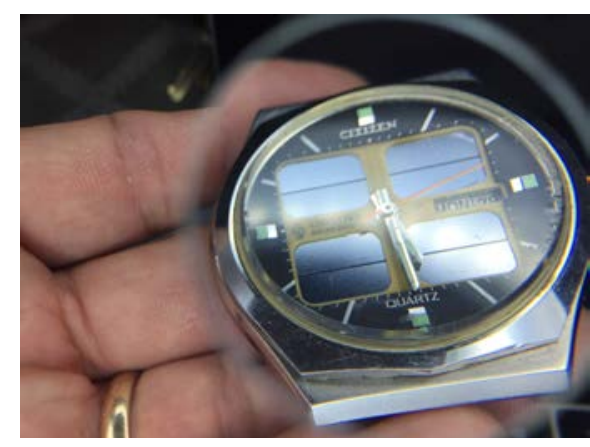

Figure 3: Citizen Crystron Solar, first solar powered analog watch, 1976.
While many other models of solar watches were produced during the late 1970s and early 1980s, the majority were from Japan. Late 1980s models utilized supercapacitors, invented by Esso in 1966 [25], to store harvested solar power, rather than batteries. Citizen Watches estimates they have saved thousands of batteries from landfill by adopting Eco-Drive strategy across the majority of their watch models. This type of system addressed in a meaningful way the issue of environmental degradation and the material limits of battery disposal. In Japan there is a particular appreciation for mercury spills from early electronics manufacture: so much so, this type of poisoning has a name: the Minimata Disease.

In Europe a variety of interesting solar powered timepieces also were created, primarily by French, German and Swiss watchmakers. For example, in the 1990s the solar-powered series of quartz 'Swatches' appeared, which also utilized supercapacitors instead of batteries. The Swatch was originally launched in 1983, around a disposable, bright 'second watch' fashion accessory made of durable plastic. Frequent colour and style changes, where each model had a different name, were a form of planned obsolescence. Long and Schiffman's 1997 article on 'Swatch Fever' discusses how Swatch established their product as collectibles by such strategies as purposely withholding the supply, inviting users to form clubs, and producing communications to encourage collecting, where the ultimate aim was to "position an ordinary object as sacred" [26].

With the introduction of the solar cell - supercapacitor power system in 1995, following up on Swatch's sponsorship of The Spirit of Biel/Bienne II solar car in 1991, Swatch seems to have been pursuing more environmentally benign products (later followed their 'Smart Car'). One solar Swatch model, the green SRG101 'Recharge', featured a printed resin band design inviting the viewer to engage in 'reviewing, rethinking, reducing, reusing and recycling' to make a 'result', with line graphics depicting recycling and the world.

But the transition of Swatch to an energy autarkic design may have only extended their run as a consumption-oriented fashion accessory. The "World Tour" SRK solar series of which $104 \mathrm{~F}$ is pictured in Figure 4, depicted iconic tourist destinations. Other models recognized designers, art exhibitions, experiences, and fashion influences. 


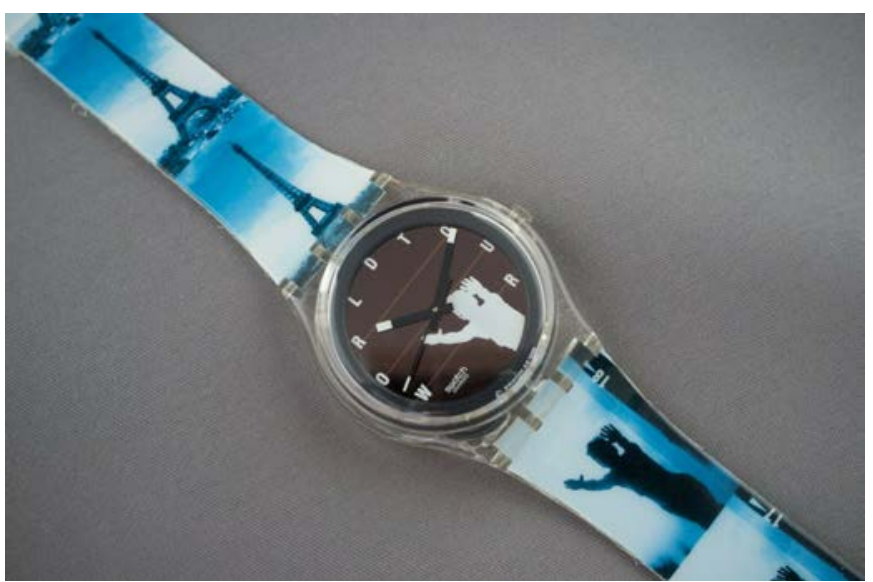

Figure 4: Swatch Solar SRK104F 'World Tour' Paris, 1997.

In a future with limits, people would need to alter their purchasing behaviour voluntarily or market choices will need to be regulated with sustainability in mind to reduce the tendency to collect consumer products without using them, or to dispose of them rather than repairing them. In this latter regard, the energy autarkic consumer products which emerged from Soviet Russia invite a stark comparison to the "Swatch".

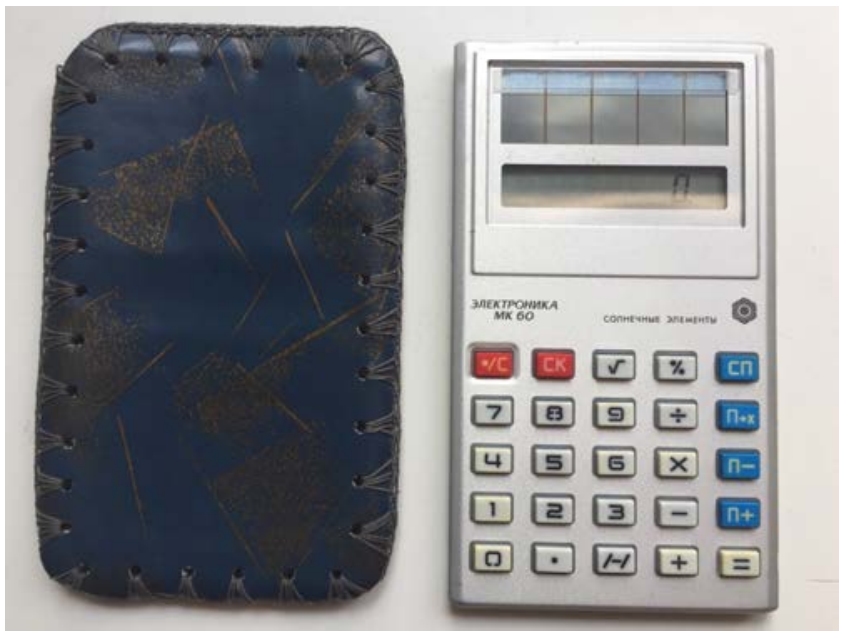

Figure 5: Elektronika MK 60 Solar Calculator, 1987- 1992

The first solar calculator was introduced by Sharp in 1976. During glasnost, or the 'openness' period of Soviet Russia in the late 1980s a number of solar powered products appeared. The first Soviet solar calculator appears to have been the Elektronika MK60. On the back of the calculator, the MK60 bears the State Quality Mark, the symbol of a pentagon with CCCP inscribed, along with a ninety degree rotated K for Kachestvo or 'quality'. This mark was used 1967-1991 to denote state-inspected products where the manufacturer could charge a higher price because of their quality certification [27]. The Elektronika MK60 was identically manufactured for a period of five years. Being solar, batteryless and durable, many are still working and available in the used market. The hand-made garment-type leather calculator sleeve is an interesting alternative to the more typical cheap plastic folding calculator case of North American markets.

\section{Energy Autarkic Games}

In 1982 solar powered games were introduced by Casio and Bandai Electronics of Japan. The Bandai LCD Solarpower series had ten gaming platforms, each with a different hard coded program and custom LCD screen. Figure 6 shows the Amazone game, which had two levels of play via a double layered LCD screen, one screen on top of the other. This series were manufactured solar and batteryless, utilizing capacitors, consequently a great many of them are still in great working order today (and prized by collectors).

In the printed game instructions there is an elaborate scientific illustration on the operation of solar cells and how they power the game, as well as specific information about the type of lighting and distance required to power it. Unfortunately, over time, the product has yellowed due to the presence of brominated fire retardants, chemicals that leach out of plastics and electronics to disrupt human endocrine development [28].

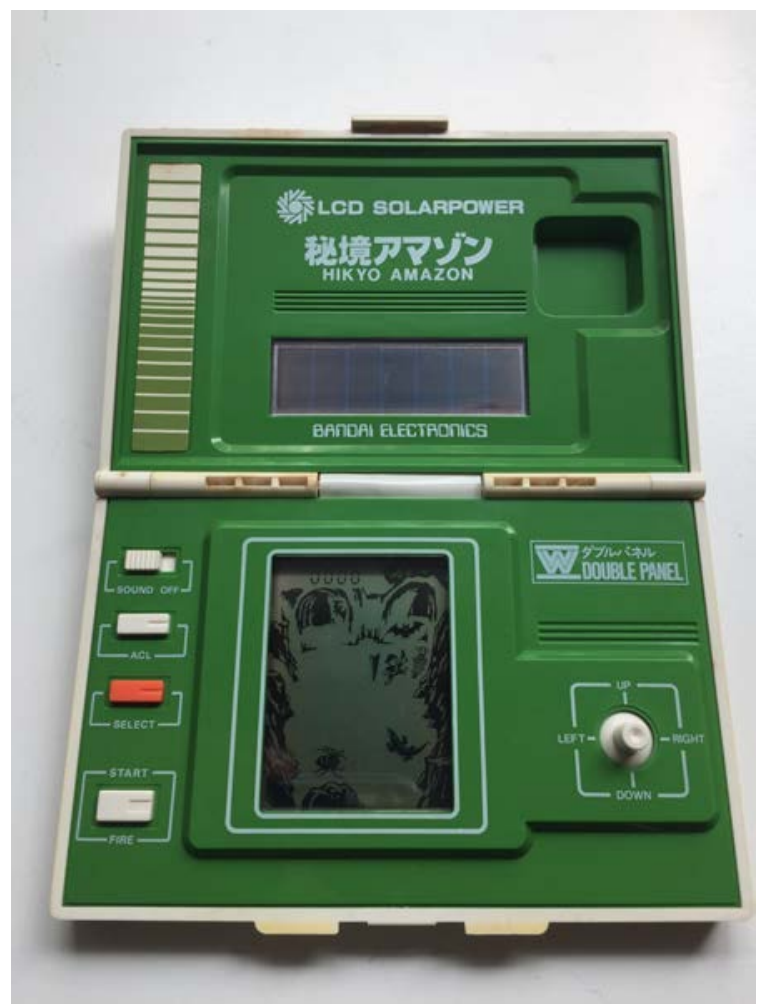

Figure 6: Amazone LCD Solarpower arcade game, 1982. 
While a great many other historical consumer devices exist that were designed solar and batteryless during this early period of solar cell manufacture (that continue to work), let us turn now to the design of more contemporary energy autarkic information systems. While there is a significant body of literature on low and no power computing design strategies for internet of things devices, I will continue this article's focus on consumer-scale devices.

\section{Energy Autarkic Smartphones}

A number of smartphones were manufactured that support charging by means of solar cells, making them relatively speaking, energy autarkic devices. The first was the Solar Guru E1107 by Samsung, introduced in 2009, which in full sun could charge the battery completely in 40 hours. This dual band GSM $2 \mathrm{G}$ phone was small, about the size of a candy or chocolate bar and priced at $\$ 60$. It supported email and SMS and could get 510 minutes of talk time for every hour of solar charging. Among its features were a 500 entry contact list, FM Radio, mp3 ringtones, two games: Soduku and 'Super Jewel Quest', a calendar app, a converter utility, a mobile tracker and SOS message sender. The FM radio requires the headphones be worn, to act as an antenna. There was also a "fake call" feature for getting out of unwanted conversations. Reviews of the phone discuss a mobile prayer app [29], although there wasn't one on the model I obtained. The battery is easily replaceable which is consistent with long term use of the product.

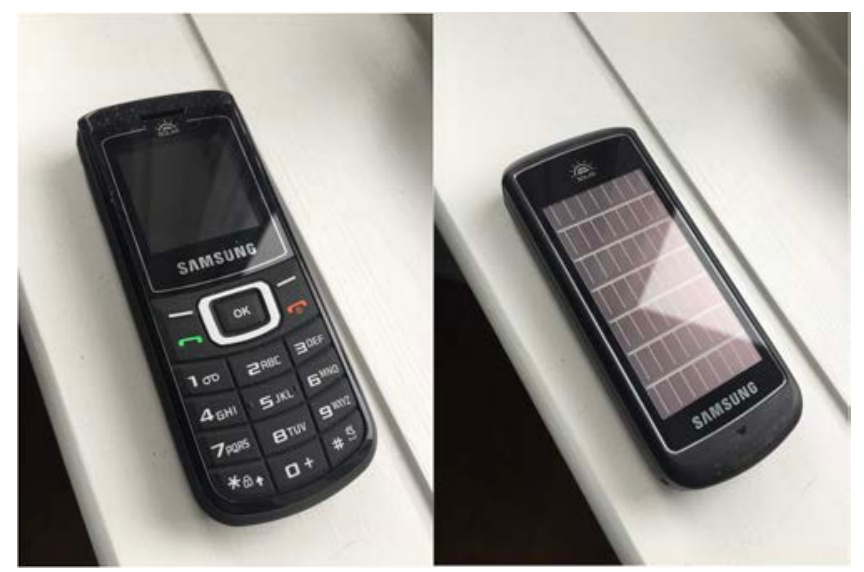

Figure 7: Samsung GT-E1107, world's first solar charged smartphone, 2009.

Samsung's second solar phone was the GT-S7550, also known as the 'Blue Earth' as the plastic was made from recycled water bottles. This was more advanced, with a touchscreen instead of buttons, Bluetooth, WiFi networking and an FM Tuner. The GTS7550 uses a standard USB micro-B cable plug, which the manual advises, must be unplugged while charging by sunlight. One hour of light will produce 5-10 minutes of talk time, as with the GT-E1107. The back cover is easily opened to replace the battery. A Wired magazine review called the phone an 'environmental champion' [30]. We might now ask of newer phones is where did the FM tuner go, in the sense streaming media is more energy intensive than a radio receiver.

The "Blue Earth" had many options around haptic testing, tracking and adjustment (the technology was new) and a lot of "features to help you protect the environment" (manual). The Eco Walk app, for example, is a pedometer which calculates one's environmental impact by walking as opposed to driving, either in carbon dioxide emissions or trees planted. An Eco Profile allows the selection of options that require less power. The Eco Display mode reduces backlighting energy usage. Eco ringtones could be selected to consume less power. The phoneunlocking system requires swipe motions around sustainability themes (wasting less water - 'close the tap', or recycling materials - 'throw away the can'). And the Eco Calendar flags specific days, such as "World Ozone Day" or "Green Consumer Day" that can be shared with others over Bluetooth or via text message.

Another solar powered cell phone produced during this period was the 2009 LG "POP" GD510. This had a haptic touchscreen, quad band GSM support, a 400 x 240 pixel, $262 \mathrm{~K}$ color TFT Touch Screen, and similar media capabilities to the Samsung "Blue Earth" GT-S7550. Rather than creating an entirely new solar powered phone, LG Electronics produced a solar cell battery cover as an accessory option, to replace the OEM back battery cover.

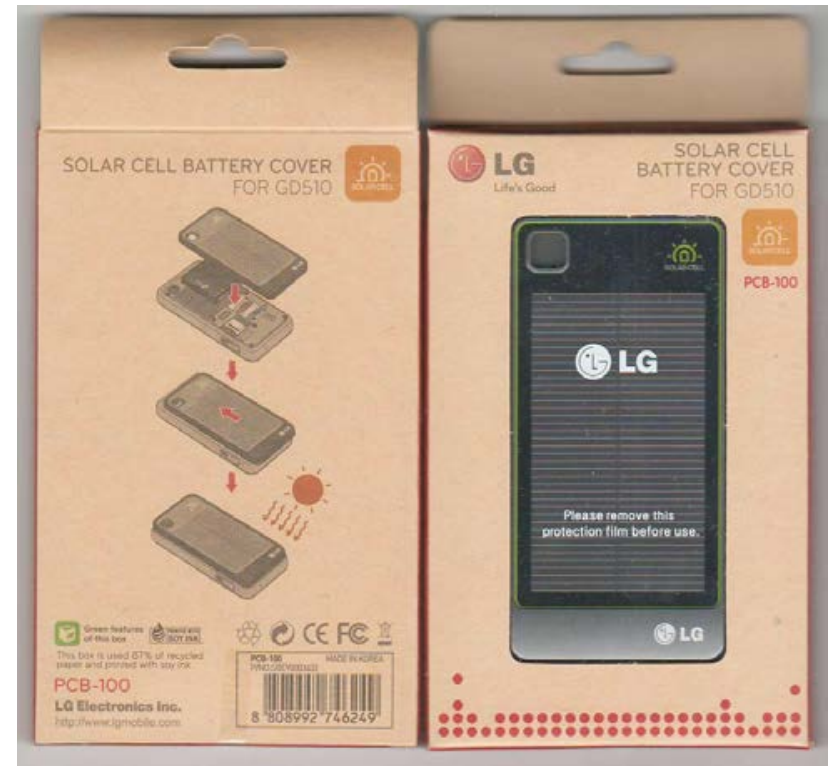

Figure 8: LG "POP" GD510 solar cell battery cover package

The LG "POP" GD510 was an entry level phone and it came in five colours: silver, black, twilight, pink and purple. The phone and solar cover are boxed in sustainable packaging, "87\% of 
recycled paper and printed with soy ink." The LG "POP" GD510 operating system recognizes when the solar cell battery cover is attached: a sun icon appears superimposed on the three-bar battery icon, which displays the level of charge. A metering system keeps track of the monthly solar charging and displays the energy saved in units of $\mathrm{mg}$ of $\mathrm{CO} 2$ emissions or trees virtually planted. A prescriptive charging eco calculator helps the user predict the charging duration required under various weather conditions.

Other manufacturers who investigated solar smartphones include Nokia, who in 2011 staged a four month open test of their 'Lokki' prototype, which was a solar case back and power unit for their existing Nokia C1-02 smartphone. The test users included a sailboat in the Baltic, a security guard in Nairobi, a teenager camping in Sweden, and a research technician in the Arctic Circle. Anecdotal results suggest that success with solar charging depended much on the deliberate circumstances in which the smartphone was used. In Kenya and in the Baltic, as the users were primarily outdoors and in full sun the phones performed well: solar charging made it possible to stay in standby mode indefinitely without mains electricity, provided the users placed the phone nearby or wore the phone on their body so it could charge [31].

We might wonder what prompted the development of these contemporary products and why they had such a short run. It may be that at the time these 'firsts' were introduced, Samsung, and LG, like Hoffman and Sharp before them, were significant industrial manufacturers of solar cells. In 2014 Kyocera, another maker both of solar panels and smartphones, announced it had licensed technology for clear photovoltaic panels that could sit between the display and the haptic touch surface, enabling a phone to be solar charged while its display was visible. The following year a prototype of this phone was demonstrated at the Mobile World Congress [32] although it was never produced in quantity. Researchers studying the solar smartphone design strategy suggest that smartphone batteries might have been made $30 \%$ smaller without affecting performance, had solar charging covers become a standard feature on smartphones [33]. However, this feature was dropped by the industry. While we'll probably never know for sure the reason, it may be the lack of confidence that people would take advantage of solar charging. Most likely it was economic: the cost per unit was high, and servicing opportunities such as battery replacement, a likely opportunity for new smartphone sales, would have been adversely impacted.

\section{Energy Autarkic Laptops}

In addition to two models of solar smartphone, Samsung introduced a solar powered netbook in 2011, the NC215S, which sold for a brief period in parts of Africa and Russia. This dual core netbook had a special, extra-large OEM battery labelled 'solar' as well as a number of features we now take for granted, such as the ability to charge a phone while the laptop is off, suspend charging the battery at $80 \%$ to conserve its life, an extra bright display for outdoor use, and the ability to report power generated from the solar panel to the system. Inside the motherboard is labelled 'Lennon-S'. While this was likely someone involved with the project, I have to wonder if it was a tribute to John Lennon, "all the people sharing all the world" in the sense the sun shines on everyone equally and without limits.

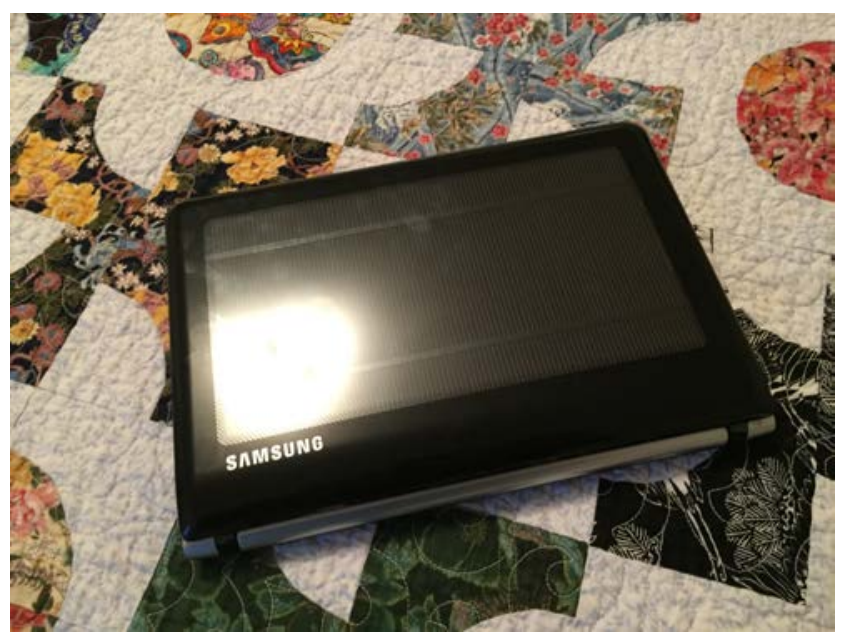

Figure 9: Samsung NC215S Netbook, 2011.

Samsung's solar devices were part of a company initiative during this period around corporate social responsibility and opening up new markets which had not crossed the digital divide. In addition to energy autarkic devices they also tested a series of energy autarkic buildings, mobile shipping containers with solar panels and high performance batteries that could be quickly brought to a remote site to provide school computer labs or health clinic services, in underserved areas. The first were tested in South Africa.

Other solar prototypes of this era include the One Laptop per Child project, a mesh capable low power computer which was tested extensively with smart charger and solar panel operation [34], and various tablet and eBook projects powered by a battery with a solar panel on the back. The Ubuntu Sol, a laptop concept developed in Canada had several solar panels that could fold out from a compartment at the back of the laptop screen. Fujitsu received a design award for a solar laptop concept named "Luce" created by Andrea Ponti Studios of Hong Kong in 2011, although no prototypes were built.

\section{Prototype Energy Autarkic Systems}

I mentioned recent efforts aimed at increasing the efficiency and energy performance of situated computing systems for monitoring and managing human environments or being integrated into products, applications known variously as 
'ubiquitous computing', the 'Internet of Things', 'pervasive computing', 'ambient intelligence', or simply 'smart -'. As a result, remarkable computing capabilities are now available in very low power configurations, powered by electricity from unusual sources such as heat differentials, electromagnetic radiation, vibration, and even biometabolic processes. Research into renewable energy components is also resulting in a variety of new high performance and environmentally benign power harvesting and storage components, making possible prototype energy autarkic systems which might previously have been dismissed as hyperbolic idealism.

One such prototype is the Battery-Free Game Boy (https://www.freethegameboy.info/) built by students of TuDelft and Northwestern University, which harkens back to the solar powered batteryless games of Bandai and Casio from forty years earlier (and my reason for including that example). The Battery Free Game Boy software features checkpointing code execution to ensure operation resumes smoothly after momentary power interruption, "the Tetris block will be in the same place" [35]. The hardware design has an Ambiq Apollo 3 ultra low power processor, FRAM non-volatile memory, with an LCD display. Energy harvesting switches render the electricity from the user's button movements and additional electricity produced by the solar cells is stored in capacitors [36]. As we have seen, unlike rechargeable batteries, capacitors are long-lasting energy storage components.

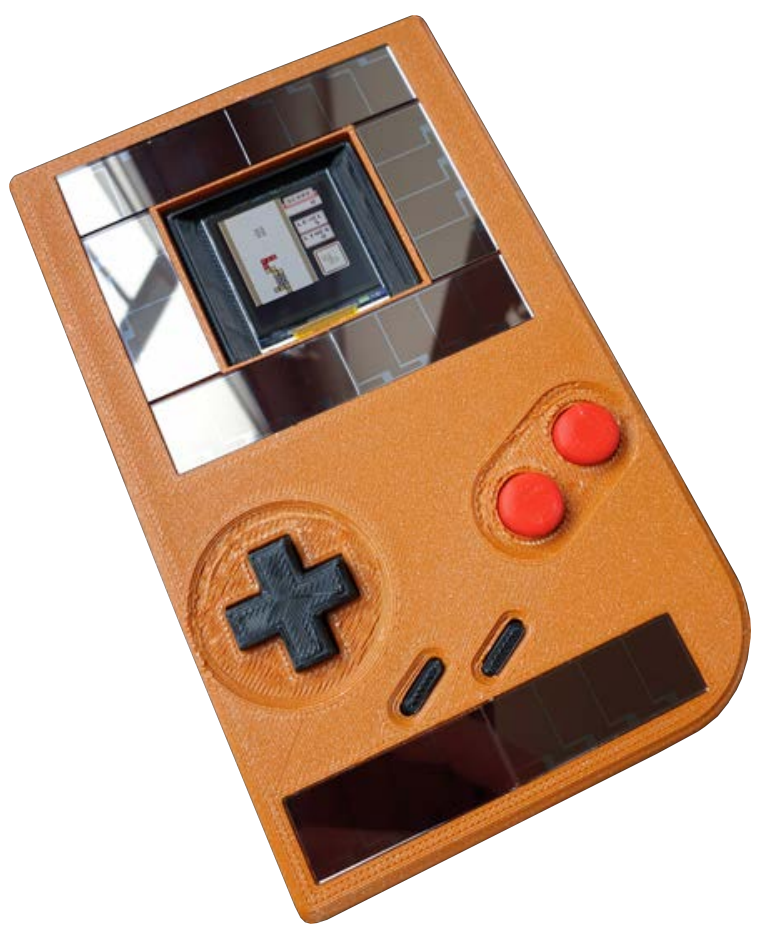

Figure 10: The "Battery Free GameBoy" - 2020 Photo by Jasper de Winkel
Another prototype system I'll discuss is the energy autarkic 'public radio' in a mason jar. The original 'public radio' uses an Atmel ATTiny microcontroller, a Silicon Labs integrated FM radio chip and a Texas Instruments amplifier IC, all designed to fit in a wide-mouth mason jar lid, programmed in Arduino and crowdfunded and launched into open source by Zach Dunham and Spencer Wright (https://thepublicrad.io). These radios work extremely well on AA batteries, and the mason jar standard affords a lot of experimentation. My energy autakric prototype substitutes four Eaton Electronics $220 \mathrm{~F}$ hybrid supercapacitors in parallel, together with a $\$ 53.6 \mathrm{~V}$ (OC) resin solar panel. Hybrid supercapacitors, which charge and discharge $3.8 \mathrm{~V}-2.2 \mathrm{~V}$, provide enough electricity under normal conditions to play the radio four or five hours a day. Overcharging them slightly on the lab bench to $3.95 \mathrm{~V}$ actually produced 13 hours of play.

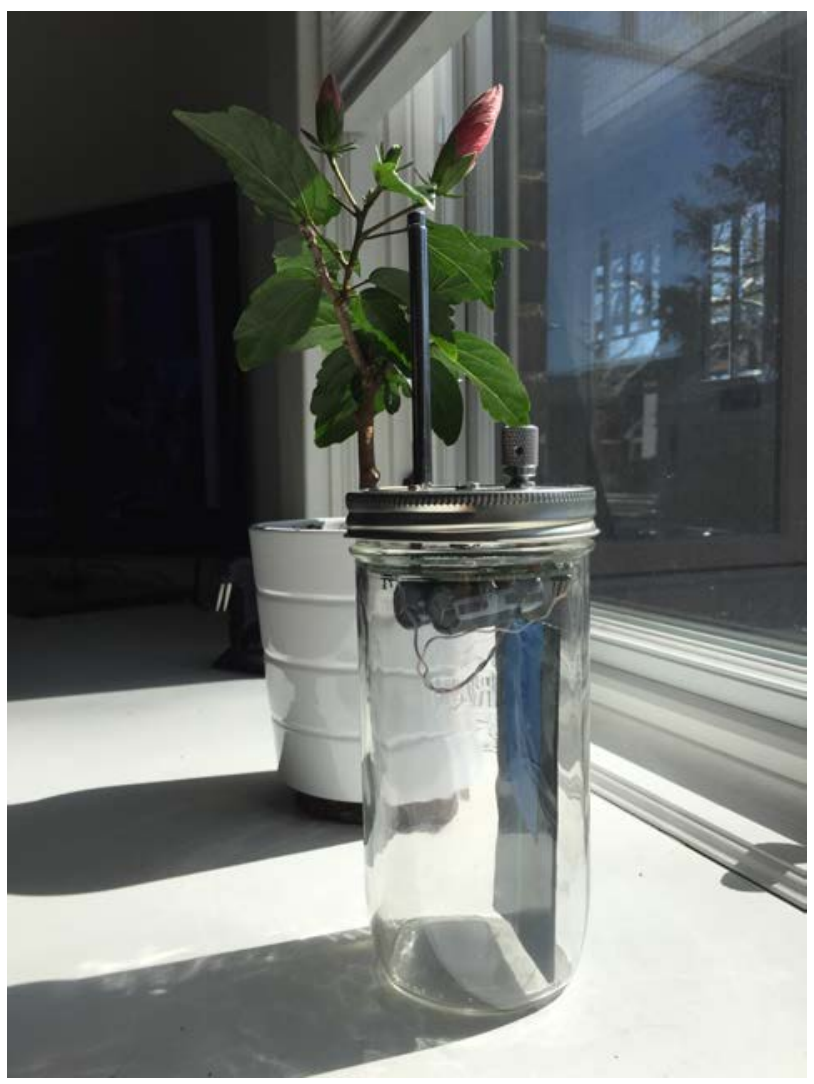

Figure 11: Energy Autarkic 'Public Radio'

\section{Aspirational Design Criteria for Energy Autarkic Systems}

While these prototype computing systems are nominal in energy harvesting and media functionality, dedicated as they are to specific tasks as opposed to high consumption multi-tasking lifestyle or business computing, they point the way to a kind of 
future where core information systems might be powered more independently by renewably sourced energy.

If computing was limited to available renewable energy and storage we would have to regulate our usage and be more individually responsible for what the environment can actually support, its real-world limits. If I forget to charge the public radio's hybrid supercapacitors by placing the jar in the sun, I have no FM radio to listen to in the evening. But, if I listen to the radio a lot and I can afford the expense, more generation capacity could be added. This speaks to a kind of approach to computing as a system, where an awareness of power consumption and component function is always part of the use - like trimming a sail to reach a destination, putting on a sweater because the weather is cold, or charging one's smartphone before going mobile, by correlating and managing the energy generation with the use, we can make smart choices about working within the limits of our local social and physical environment, rather than suffering our information system excesses on faraway, 'cloudy' places supported by coal-fired and gas electricity generation.

While individual users might choose consumer choices inclined toward sustainability and so shift the free market (if you believe in the neoliberalist view that individuals have a lot of agency), repairing and upcycling products over DIY networks often helps consumers to recognize how much of a role manufacturing and marketing plays in actually controlling the market. Practices such as limiting the supply and demand and therefore the price and choice, offering cheaper products which generate more profit but with dubious environmental effects, fostering consumption-oriented consumer behaviour and ongoing service dependencies, needless or difficult repairs, the continued use of dangerous materials, and acquiring intellectual property which might promote durability or energy saving improvements is antithetical to the needs of consumers and the public good in a future with limits. The persistence and success of these controlling strategies in the market suggests that governments need to play more of an active role in steering markets toward sustainable practice.

Even so, within the solar consumer products explored in this very short and limited history of energy autarkic information systems, a few emerged which provide significant material savings, durable reusability to consumers, and were successful to the degree they have been continuously produced since their inception (and still work).

I suggest the following aspirational design criteria for energy autarkic systems:

1. Ultra-low power standby modes to eliminate energy waste. Some Citizen Eco-Drive movements are able to keep accurate time for seven years without solar illumination, in power save mode

2. Hardware and software designs of the highest energy and material efficiency. ARM processors are among the most energy efficient; the FRAM chips used on the Battery-Free Game Boy are remarkably low power and non-volatile (100 trillion read-writes, 150 year data retention) [37]
3. Open hardware and software designs, so aspects of a system can be adapted by the user and problems encountered can be solved. For example, I can adjust the tuning button's response time on the public radio by downloading the Arduino code posted on GitHub and writing over the software of the ATTiny microcontroller with my own updates

4. Use of universal component and connection standards and interchangeable parts such as USB to ensure current and future compatibility between devices

5. Durability and the ability to reuse, repurpose, repair or upcycle devices. Since energy autarkic systems provide service from ambient energy at near-zero marginal cost, they provide a significant value over their lifetime for the initial investment of their design, manufacture and recycling, but only if they are designed to continue working and be upgraded. The cessation of $2 \mathrm{G}$ networks has meant many early smartphones' primary function is no longer supported. Half-century old devices that used capacitors instead of batteries are still working reliably.

6. Material recyclability. From the historical examples it is clear that environmental degradation can be a significant part of manufacturing. A sustainably powered autarkic AM radio like the 1959 Hoffman Trans-Solar may still receive AM stations but very little of these radios can be recycled, due to the lead, mercury, and phenolic plastics used in their manufacture. A more thorough life cycle analysis is required around the creation of new electronics products and environmental impact. Supercapacitors and indoor organic solar cells in their emerging capabilities have the potential to improve the environmental footprint of energy autarkic electronics.

While design aspirations around energy autarky of individual devices goes partways toward addressing the sustainability and limits of computing, interconnected networks and systems might similarly be examined around the organizational principles of efficiency and energy autarky. One such proposition is "Solar Protocol" by Brooklyn artists Tega Brain, Alex Nathanson and Benedetta Piantella. A series of internet servers powered by solar panels have their traffic requests routed based on which computer is the closest server harvesting sustainable energy in full sun [38]. (http://solarprotocol.net/). If a server in the network has scarce energy, then the web site reverts to a power saving, low resolution mode, similar to the design developed for a low-energy solar powered website in Barcelona (https://www.lowtechmagazine.com/) [39].

Systems which integrate energy generation and consumption engage users to manage their energy thoughtfully and mindful of the limits. Once constructed, these devices do not impose a significant burden on the energy or environmental resources of the planet and there is equity in this principle: the sun shines on everyone and without limit. Aspirations around energy justice, the digital divide and cultural independence within sociotechnical systems in places like the Global South may well be served by harnessing solar energy to net-positive civic digital infrastructure on decentralized open platforms. Along with a total lifecycle approach to the materiality and durability of computing, the energy autarky of information systems design supports natural limits on service, creates resilience, and these 
transitional design criteria address the definition of computing within limits as "design and development of computing systems in the abundant present for use in a future of limits or scarcity"[40]. Put simply, with reasonable maintenance and care, energy autarkic inforrmation systems are guaranteed a future abundance of energy to ensure their function.

\section{ACKNOWLEDGEMENTS}

Zenith Electronics LLC, for the reproduction of the Royal 555 Suncharger illustration.

\section{REFERENCES}

[1] Matthias Otto Müller, Adrian Stämpfli, Ursula Dold, and Thomas Hammer. 2011. Energy autarky: A conceptual framework for sustainable regional development. Energy Policy 39, 10 (October 2011), 5800. DOI:https://doi.org/10.1016/j.enpol.2011.04.019

[2] Daniel A Barber. 2021. Active Passive: Heat Storage and the Solar Imaginary. The South Atlantic quarterly 120, 1 (2021), 103DOI:https://doi.org/10.1215/00382876-8795754

[3] Louis Columbus. 2016. Roundup of Internet of Things Forecasts and Market Estimates, 2016. Forbes (2016).

https://www.forbes.com/sites/louiscolumbus/2016/11/27/roundup-of-internetof-things-forecasts-and-market-estimates-2016

[4] Ian Bitterlin. 2013. Sustainability for and by Information Communications Technology (ICT) [White Paper], 8. Retrieved March 13, 2018 from https://shop.bsigroup.com/upload/Sustainability\%20Downloads/BSISustainability-for-and-by-ICT-Whitepaper.pdf.

[5] Chloe Fletcher and Jigna Chandaria. 2020. The energy footprint of BBC radio services: now and in the future. Retrieved from https://downloads.bbc.co.uk/rd/pubs/whp/whp-pdf-files/WHP393.pdf

[6] Brett H. Robinson. 2009. E-waste: An assessment of global production and environmental impacts. Science of The Total Environment 408, 2 (December 2009), 183-191. DOI:https://doi.org/10.1016/j.scitotenv.2009.09.044

[7] Gary Cook and Elizabeth Jardim. 2019. Clicking Clean Virginia: The Dirty Energy Powering Data Center Alley. Retrieved April 2, 2021 from https://www.greenpeace.org/usa/reports/click-clean-virginia/

[8] Ron Diebert. 2020. CBC Massey Lecture \#5: Burning Data. Retrieved from https://www.cbc.ca/radio/ideas/want-to-help-save-the-planet-hang-ontoyour-old-smartphone-1.5799102

[9] Supreeth Subramanya, Zain Mustafa, David Irwin, and Prashant Shenoy. 2015. Energy-Agility: A New Grid-centric Metric for Evaluating System Performance. In LIMITS 2015, Irvine, CA, USA, 5. Retrieved from https://computingwithinlimits.org/2015/papers/limits2015-subramanya.pdf

[10] Barath Raghavan and Shaddi Hasan. 2016. Macroscopically Sustainable Networking: On Internet Quines. In LIMITS 2016, Irvine, CA, USA, 6. Retrieved from https://computingwithinlimits.org/2016/papers/a11raghavan.pdf

[11] Barath Raghavan. 2015. Abstraction, Indirection, and Sevareid's Law: Towards Benign Computing. In LIMITS 2015, Irvine, CA, USA, 4. Retrieved from https://computingwithinlimits.org/2015/papers/limits2015-raghavan.pdf

[12] Alan Borning, Batya Friedman, and Deric Gruen. 2018. What Pushes Back from Considering Materiality in IT? In LIMITS 2018, Toronto, Canada, 6. Retrieved from https://doiorg.myaccess.library.utoronto.ca/10.1145/3232617.3232627

[13] Scientific American. 1883. SOLAR MACHINERY. Scientific American 49, 7 (1883), 97.

[14] D. M. Chapin, C. S. Fuller, and G. L. Pearson. 1954. A New Silicon p-n Junction Photocell for Converting Solar Radiation into Electrical Power. Journal of Applied Physics 25, 5 (May 1954), 676-677. DOI:https://doi.org/10.1063/1.1721711

[15] Esquire Magazine Advertisement. 1958. Free Power from the Sun ... This Year's Newest ... Most Exciting .. Most Wanted Gift. Esquire (Advertising Insert), 50GG.

[16] John Perlin. 1999. From Space to Earth: the story of solar electricity. Aatec Publications, Ann Arbor, MI, 26.

[17] Julian F. Randall. 2005. Designing indoor solar products: photovoltaic technologies for AES. J. Wiley \& Sons, Hoboken, N.J.

[18] Georgia Apostolou and Angèle H. M. E. Reinders. 2014. Overview of Design Issues in Product-Integrated Photovoltaics. Energy Technology 2, 3 (2014), 229-242. DOI:https://doi.org/10.1002/ente.201300158

[19] Frank Capra Productions. 1956. Our Mr. Sun. Retrieved March 17, 2019 from http://archive.org/details/our_mr_sun
[20] Frank Capra Productions. 1958. The Unchained Goddess 1958 - Bell Science Hour (Discusses Weather / Climate Change). Retrieved April 2, 2021 from https://youtu.be/x1ph_7C1Jq4?t=3012

[21] Michael N. Rosenblatt, Christopher David Prest, Fletcher Rothkopf, and Aaron Leiba. 2008. Solar cells on portable devices. Retrieved October 10, 2019 from https://patents.google.com/patent/US20080094025A1/en

[22] Wendell B. Sander, Daniel A. Warren, and Aaron Leiba. 2011. Methods and apparatuses for operating devices with solar power. Retrieved November 2, 2020 from https://patents.google.com/patent/US8004113B2/en

[23] Zenith. 1955. The Zenith Story: A History from 1919. Zenith Radio Corporation, Chicago, 12.

[24] John Perlin. 1999. From Space to Earth: the story of solar electricity. Aatec Publications, Ann Arbor, MI, 135.

[25] Robert A. Rightmire. 1966. Electrical energy storage apparatus. Retrieved April 2, 2021 from https://patents.google.com/patent/US3288641A/en

[26] Mary M Long and Leon Schiffman. 1997. Swatch Fever: An Allegory for Understanding the Paradox of Collecting. Psychol. Mark. 14, 5 (August 1997), $15,507$.

[27] State quality mark of the USSR. Wikipedia. Retrieved April 2, 2021 from https://en.wikipedia.org/w/index.php?title=State_quality_mark_of_the_USSR \&oldid $=959981121$

[28] Rita-Josiane Gouesse, Elham Dianati, Alec McDermott, Michael G Wade, Barbara Hales, Bernard Robaire, and Isabelle Plante. 2021. In Utero and Lactational Exposure to an Environmentally Relevant Mixture of Brominated Flame Retardants Induces a Premature Development of the Mammary Glands. Toxicological Sciences 179, 2 (February 2021), 206-219. https://doi.org/10.1093/toxsci/kfaa176

[29] Times of India Tech. 2010. World's first solar-powered cellphone - Times of India. The Times of India. Retrieved August 23, 2020 from https://timesofindia.indiatimes.com/gadgets-special/Worlds-first-solarpowered-cellphone/articleshow/6100719.cms

[30] Charlie Sorrel. 2009. Blue Earth: Samsung's Solar Phone Made from Water Bottles. Wired Gear. Retrieved from https://www.wired.com/2009/02/blueearth-sams/

[31] Don. 2012. Nokia's Mobile Phone Solar Charging Project. Energy Matters. Retrieved April 2, 2021 from https://www.energymatters.com.au/renewablenews/em1970/

[32] Lynn La. 2015. Kyocera showcases concept devices and Windows Phone prototype at MWC 2015. CNET. Retrieved September 8, 2020 from https://www.cnet.com/news/kyocera-concept-devices-mwc-2015/

[33] Georgia Apostolou and Angèle H. M. E. Reinders. 2014. Overview of Design Issues in Product-Integrated Photovoltaics. Energy Technology 2, 3 (2014), 238.

[34] Chris Bell. 2012. OLPC XO laptop powered by a solar panel. Retrieved April 2, 2021 from https://www.youtube.com/watch?v=ITHNbOrPQyM

[35] Jasper de Winkel. Vito Kortbeek, Josiah Hester, and Przemyslaw Pawelczak. 2020.. Free The Game Boy. Retrieved April 2, 2021 from https://www.freethegameboy.info/

[36] Jasper de Winkel, Vito Kortbeek, Josiah Hester, and Przemyslaw Pawelczak. 2020. Battery-free GameBoy. IMWUT 4, 3 (2020), 111.

[37] Cypress Semiconductor. 2019. 4-Mbit $(256 \mathrm{~K} \times 16)$ F-RAM Datasheet. Retrieved from https://www.cypress.com/file/136476/download

[38] Tega Brain, Alex Nathanson and Benedetta Piantella. 2021. Solar Protocol. Retrieved April 2, 2021 from http://solarprotocol.net/

[39] Marie Otsuka and Lauren Traugott-Campbell. 2019. Solar Powered Website. Toronto Media Arts Centre. Retrieved April 8, 2021 from https://www.youtube.com/watch?v=p3oK4-MhfgQ

[40] Daniel Pargman, Aksel Biørn-Hansen, Elina Eriksson, Jarmo Laaksolahti, and Markus Robèrt. 2020. From Moore's Law to the Carbon Law. In Proceedings of the 7th International Conference on ICT for Sustainability (ICT4S2020), Association for Computing Machinery, New York, NY, USA, 285-293. DOI:https://doi.org/10.1145/3401335.3401825 